\title{
Confirmation of Strain VKM B-1733 as the Type Strain of Halorubrum distributum
}

\author{
A. OREN, ${ }^{1 *}$ M. KAMEKURA, ${ }^{2}$ AND A. VENTOSA ${ }^{3}$ \\ The Alexander Silberman Institute of Life Sciences and The Moshe Shilo Center for Marine Biogeochemistry, \\ The Hebrew University of Jerusalem, 91904 Jerusalem, Israel ${ }^{1}$; Noda Institute for Scientific Research, \\ 399 Noda, Noda-shi, Chiba-ken 278, Japan²; and Departamento de Microbiologia y \\ Parasitologia, Facultad de Farmacia, Universidad de Sevilla, 41012 Seville, Spain ${ }^{3}$
}

\begin{abstract}
In a recent paper, Zvyagintseva et al. (I. S. Zvyagintseva, E. B. Kudryashova, and E. S. Bulygina, Microbiology [Engl. Trans. Mikrobiologiya] 65:352-354, 1996) proposed that strain 4p, deposited as VKM B-1739, should be the new type strain of Halobacterium (Halorubrum) distributum. This strain is sufficiently different from the validated type strain (strain 1m $[=$ VKM B-1733]) to be classified in a different species. The proposed establishment of a neotype strain for Halorubrum distributum while the originally designated type strain is extant is in conflict with Rule 18c of the International Code of Nomenclature of Bacteria. To avoid all confusion, strain VKM B-1733 should remain the type strain of Halorubrum distributum, and a new species may be proposed to include VKM B-1739 and a number of related isolates.
\end{abstract}

In 1987, Zvyagintseva and Tarasov described a new type of halophilic archaeon, isolated from saline soil, which was different from the previously known members of the family Halobacteriaceae. A new species, Halobacterium distributum (originally Halobacterium distributus) (12), was defined. Halobacterium distributum was validated as a new species, and strain $1 \mathrm{~m}$, deposited as VKM B-1733, was designated the type strain (1). The recent reclassification of species previously included in the genus Halobacterium $(3,6)$ and the validation of the new genus Halorubrum (2) made it necessary to change the name Halobacterium distributum to Halorubrum distributum (7). Inclusion of Halobacterium distributum in the newly proposed genus Halorubrum (Halorubrobacterium) was based in part on the 16S rRNA sequence of strain JCM 9100, which was derived from VKM B-1733 ${ }^{\mathrm{T}}$ ( $\mathrm{T}=$ type strain) $(3)$.

An additional strain (strain 4p, deposited as VKM B-1739 and also named Halobacterium distributum) was used in later cytological and physiological studies $(4,8)$. In a paper published in 1995 Zvyagintseva and coworkers (10) designated strain VKM B-1739 the type strain of Halobacterium distributum, but no explanation was given for the change. To add to the confusion, Tindall (9) gives as type strain of Halobacterium distributum strain 1m (= VKM B-1739), a combination that does not exist.

A proposal to establish strain $4 \mathrm{p}(=\mathrm{VKM}$ B-1739) as the new type strain of Halobacterium (Halorubrum) distributum was published recently (11). On the basis of DNA-DNA homology data and 5S and 16S rRNA nucleotide sequences it was concluded that strain VKM B-1739 and a number of additional isolates (VKM B-1916D, VKM B-1954, and INMI 502) assigned to the species Halobacterium (Halorubrum) distributum are sufficiently different from strain VKM B-1733 ${ }^{\mathrm{T}}$ to be placed in a different species (DNA-DNA hybridization values, around $60 \%$ ). The authors suggested that, based on similarities in $16 \mathrm{~S}$ rRNA nucleotide sequences, strain VKM B-1733 ${ }^{\mathrm{T}}$ may be related to Halobacterium (Halorubrum) trapanicum and that "For the species identification of strain VKM B-1733, it is

\footnotetext{
* Corresponding author. Mailing address: Division of Microbial and Molecular Ecology, Institute of Life Sciences, The Hebrew University of Jerusalem, 91904 Jerusalem, Israel. Phone: 972-2-6584951. Fax: 972-2 6528008. E-mail: orena@shum.cc.huji.ac.il.
}

necessary to carry out DNA-DNA hybridization with the type strain Halobacterium trapanicum NRC 34021" (a strain no longer available to our knowledge).

The conclusion of Zvyagintseva and coworkers that Halobacterium distributum VKM B-1733, which was previously considered the type strain of Halobacterium distributum, cannot be assigned to this species, is incorrect. The properties on which the description and validation of the species Halorubrum (Halobacterium) distributum were based were those of the type strain designated at the time of the species description (i.e., strain VKM B-1733). When other isolates have different properties, they should be classified in different taxa, and there is no justification for designating another, greatly different strain as the new type strain when it is more convenient for certain purposes.

The establishment of a neotype strain for Halorubrum distributum, as proposed by Zvyagintseva and coworkers, is not possible within the rules of the Bacteriological Code (5). The only conditions under which a neotype strain may be designated are described in Rule $18 \mathrm{c}$, which deals with cases in which the strain on which the original description was based cannot be found. Rule $18 \mathrm{~d}$ states that "A strain suggested as a neotype but not formally proposed in accordance with the requirements of Rule 18c (suggested neotype) has no standing in nomenclature until formally proposed and established." As the validated type strain of Halorubrum distributum is available from culture collections, there is no reason for the proposal of a neotype. If the type strain has become unsuitable due to changes in its characteristics or for other reasons, the matter should be referred to the Judicial Commission, as Rule $18 \mathrm{~g}$ demands. In our opinion there is no justification in the present case to warrant such a step. Therefore, strain VKM B-1733 should remain the type strain of Halorubrum distributum.

The data presented by Zvyagintseva and coworkers (11) convincingly show that while strain VKM B-1739 belongs to a species different from Halorubrum distributum as represented by type strain VKM B-1733, it is a member of the genus Halorubrum. This appears to be the case from the polar lipid composition and from the presence of signature bases CA and TG in positions 17 and 18 and positions 25 and 26, respectively (11), combinations found in all Halorubrum species that have been described (and also in Natronobacterium pharaonis) (2a). Therefore, we suggest that Zvyagintseva et al. to describe and 
validate a new species of Halorubrum and include a full phenotypic characterization. This new species should preferably have strain 4p (= VKM B-1739) as its type strain and should include related strains VKM B-1916D, VKM B-1954, and INMI 502.

\section{REFERENCES}

1. International Journal of Systematic Bacteriology. 1989. Validation of the publication of new names and new combinations previously effectively published outside the IJSB. List no. 31. Int. J. Syst. Bacteriol. 39:495-497.

2. International Journal of Systematic Bacteriology. 1996. Validation of the publication of new names and new combinations previously effectively published outside the IJSB. List no. 56. Int. J. Syst. Bacteriol. 46:362-363.

2a.Kamekura, M. Unpublished data.

3. Kamekura, M., and M. L. Dyall-Smith. 1995. Taxonomy of the family Halobacteriaceae and the description of two new genera, Halorubrobacterium and Natrialba. J. Gen. Appl. Microbiol. 41:333-350.

4. Kostrikina, N. A., I. S. Zvyagintseva, and V. I. Duda. 1990. Cytological peculiarities of Halobacterium distributus, an extreme halophilic archaebacterium. Microbiology (Engl. Transl. Mikrobiologiya) 59:70-74.

5. Lapage, S. P., P. H. A. Sneath, E. F. Lessel, V. B. D. Skerman, H. P. R Seeliger, and W. A. Clark (ed.). 1992. International code of nomenclature of bacteria: bacteriological code, 1990 revision. American Society for Microbiology, Washington, D.C

6. McGenity, T. J., and W. D. Grant. 1995. Transfer of Halobacterium saccha- rovorum, Halobacterium sodomense, Halobacterium trapanicum NRC 34041 and Halobacterium lacusprofundi to the genus Halorubrum gen. nov., as Halorubrum saccharovorum comb. nov., Halorubrum sodomense comb. nov., Halorubrum trapanicum comb. nov., and Halorubrum lacusprofundi comb. nov. Syst. Appl. Microbiol. 18:237-243.

7. Oren, A., and A. Ventosa. 1996. A proposal for the transfer of Halorubrobacterium distributum and Halorubrobacterium coriense to the genus Halorubrum as Halorubrum distributum comb. nov. and Halorubrum coriense comb. nov. respectively. Int. J. Syst. Bacteriol. 46:1180.

8. Tarasov, A. L., I. S. Zvyagintseva, and V. K. Plakunov. 1991. Citrate transport in Halobacterium distributum cells. Microbiology (Engl. transl. Mikrobiologiya) 60:19-23.

9. Tindall, B. J. 1992. The family Halobacteriaceae, p. 768-808. In A. Balows, H. G. Trüper, M. Dworkin, W. Harder, and K.-H. Schleifer (ed.), The prokaryotes. A handbook of bacteria: ecophysiology, isolation, identification, applications, vol. 1. Springer-Verlag, New York, N.Y.

10. Zvyagintseva, I. S., L. I. Gerasimenko, N. A. Kostrikina, E. S. Bulygina, and G. A. Zavarzin. 1995. Interaction of halobacteria and cyanobacteria in a halophilic cyanobacterial community. Microbiology (Engl. transl. Mikrobiologiya) 64:209-214.

11. Zvyagintseva, I. S., E. B. Kudryashova, and E. S. Bulygina. 1996. Proposal of a new type strain of Halobacterium distributum. Microbiology (Engl. transl. Mikrobiologiya) 65:352-354.

12. Zvyagintseva, I. S., and A. L. Tarasov. 1987. Extreme halophilic bacteria from saline soils. Microbiology (Engl. transl. Mikrobiologiya) 56:664-669. 